
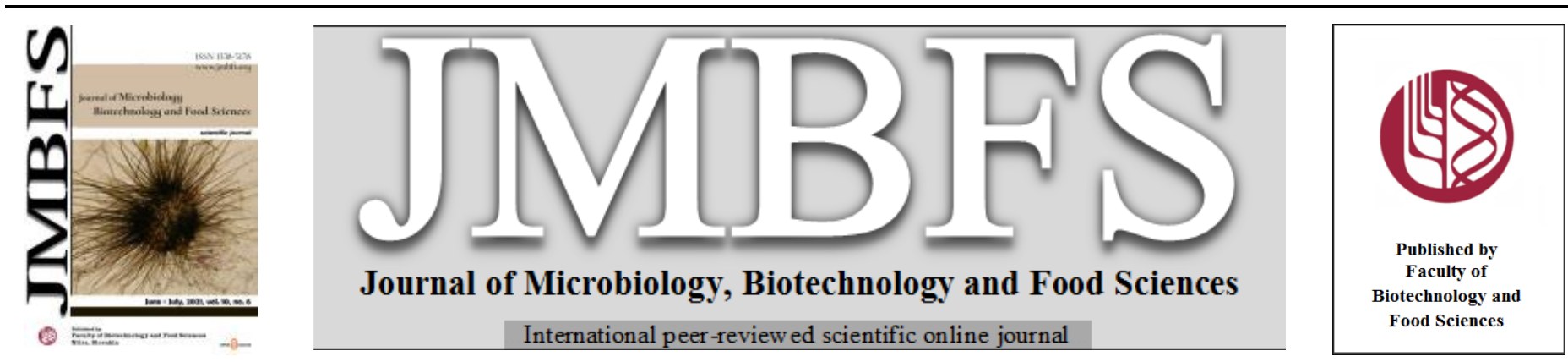

\title{
PARTS FROM LIFE-CYCLE OF H.ERINACEUS: RESPONSE SURFACE METHODOLOGY APPROACH TO OPTIMIZE EXTRACTION CONDITIONS AND DETERMINATION OF ITS ANTIOXIDANT, ANTIDIABETIC AND ANTIMICROBIAL EFFECT
}

\author{
Nurcan Doğan*1, Cemhan Doğan ${ }^{1}$, Funda Atila ${ }^{2}$ \\ Address(es): Assist.Prof. Nurcan Doğan, \\ ${ }^{1}$ Department of Food Technology, Yozgat Boğazliyan Vocational High School, Yozgat Bozok University 66400 , Yozgat, Turkey, +90 $3542903002-7026$. \\ ${ }^{2}$ Department of Horticulture, Faculty of Agriculture, Ahi Evran University, 40200, Kırşehir, Turkey, +90 3862804814.
}

*Corresponding author: nurcan.dogan@bozok.edu.tr

https://doi.org/10.15414/jmbfs.3703

\section{ARTICLE INFO}

Received 11.9. 2020

Revised 26. 12. 2020

Accepted 28. 12. 2020

Published 1. 6. 2021

Regular article

open $\mathcal{O}$ access

\begin{abstract}
In this article, optimization of extraction conditions of different parts from the life cycle of H.erinaceus was investigated based on Response Surface Method. Furthermore, antioxidant, antidiabetic, and antimicrobial effects of optimized extracts were studied. Results: Temperature, liquid / solid ratio, and solvent concentration significantly affected the phenolic content and antioxidant capacities of all samples. The young fruit body of H.erinaceus had higher antioxidant $(43.11 \pm 2.74,51.39 \pm 2.34,62.84 \pm 1.59 \mu \mathrm{mol}$ TE/g for DPPH, FRAP and ABTS, respectively) and antidiabetic effects $(93.54 \pm 2.3$ and $132.25 \pm 1.38 \mu \mathrm{g} / \mathrm{mL}$ for IC50 values of $\alpha$-glucosidase and $\alpha$-amylase, respectively) than mycelium. However, these effects partially decrease as the fruit body ages. Besides, the optimized extracts exhibited more antimicrobial effects on Gram-positive bacteria than Gram-negative bacteria. Conclusion: Both the fruit body and the mycelium of H.erinaceus have many bio-functional properties. However, these properties of the fruit body decrease significantly with the delay of the harvest time. The extraction process conditions we optimize in this study can be adapted to large-scale separation processes in the industry.
\end{abstract}

Keywords: Antidiabetic, Antimicrobial, Antioxidant, Hericium erinaceus, Optimization

\section{INTRODUCTION}

Hericium erinaceus is an edible medicinal mushroom species in the Hericiaceae family. $H$. erinaceus, also known by names like lion's mane and monkey head, has a unique appearance with spines longer than $1 \mathrm{~cm}$. Numerous bioactive components of this mushroom have many effects, such as antioxidant (Ferreira et al., 2009), anti-aging (Nakatsugawa et al., 2003), immunomodulatory (Lee and Hong, 2010), antitumor (S. P. Kim et al., 2011), antimicrobial (Wong et al., 2009), and antihyperglycemic (Wang et al., 2005). These components in H.erinaceus are found both in the fruit body and in the mycelia. However, the amount of components in the fruit body of the mushroom varies according to the degree of fruit maturity ( $\mathbf{L i}$ et $\boldsymbol{a l} ., \mathbf{2 0 1 5})$. The production of medicinal mushrooms is a complex process due to parameters such as media content, hygienic requirements, and adequacy of artificial conditions. Also, even if previously supplied liquid or grain spawn is used in cultivation, the fruit body can usually be collected after a few months (Stamets, 2011). Mycelial biomass can be produced in a short time with high efficiency with the technique of submerge fermentation (Fang and Zhong, 2002). Whether it is mycelium or the fruit body, H.erinaceus has significant effects on human health, which has rapidly increased its use in food supplements in recent years.

Extraction conditions are vital for the recovery and subsequent purification of bioactive components from biomass. These conditions, such as temperature, liquid/solid ratio, and solvent concentration, may significantly change the nature and activity of the extract (Chirinos et al., 2007). Therefore, extraction conditions need to be optimized for the desired objectives. The traditional optimization method, where only one variable is optimized at a time, can only be completed by performing a large number of experiments that cause excessive resource and time consumption. Moreover, interactions between variables may be ignored, and discrepancies may occur when individually optimized variables are applied together. In Response Surface Methodology (RSM), which was first introduced by Box and Wilson (1992), unlike the traditional optimization method, the effect of multiple variables on responses can be evaluated as a whole. Thus, errors that may occur due to the interaction of variables are minimized, and the results can be better evaluated. Furthermore, RSM requires few experiments in the optimization process, which means time and resource savings. Therefore, many researchers have successfully applied RSM to extract components from mushrooms and to optimize extraction process conditions (Gogoi et al., 2019; XuJie and Wei, 2008). However, studies on the optimization of the extraction process of H.erinaceus are limited.

The objectives of this work were; to optimize extraction processes of mycelium and fruit body (with two different maturity stages) of H.erinaceus according to the total phenolic content (TPC) and antioxidant capacity based on RSM approach, and to determine and compare the antioxidant, antimicrobial and antidiabetic effects of optimized extracts.

\section{MATERIAL AND METHODS}

\section{Materials}

Pure culture of H.erinaceus obtained from Culture Collection at the Ahi Evran University (Kırşehir, Turkey) were inoculated on Malt Extract Agar (MEA) plates. After incubation at $25^{\circ} \mathrm{C}$ for ten days, it was used for both mycelial biomass production and mushroom cultivation. Wheat bran and poplar sawdust used for the growing medium of mushrooms were provided from local suppliers in Yozgat province. All chemicals used in this study were purchased from Merck $\mathrm{KGaA}$ unless otherwise stated.

\section{Mycelial biomass production}

The fully colonized media was divided into two equal parts with a scalpel. Then one of them was transferred in a sterile stainless steel blender container (Waring 8011 ES blender, NJ, USA) and homogenized with $100 \mathrm{~mL}$ of distilled water. After homogenization, $10 \mathrm{~mL}$ of mycelium-enriched liquid was poured into a $250 \mathrm{~mL}$ Erlenmeyer flask containing $90 \mathrm{~mL}$ of broth prepared with $20 \mathrm{~g} / \mathrm{L}$ light malt extract, $5 \mathrm{~g} / \mathrm{L}$ dry yeast extract, $1 \mathrm{~g} / \mathrm{L} \mathrm{K}_{2} \mathrm{PO}_{4}$ and $0.5 \mathrm{~g} / \mathrm{L} \mathrm{MgSO}_{4}$. After the Erlenmeyer flask was closed with non-absorbent cotton, mixture, which was formulated based on Lee et al. (2009) with some modifications, was incubated in a shaking water bath (Daihan MaXturdy-45, Korea) at $25^{\circ} \mathrm{C}$. At the end of the 14 days incubation, the liquid was centrifuged at $4000 \mathrm{rpm}$ for $5 \mathrm{~min}$ (Nüve, Turkey), and the precipitate was named as mycelial biomass (MB). 


\section{Preparation and inoculation of substrate}

The method used in this section was performed based on Ko et al. (2005) with some modifications. Poplar sawdust was mixed with wheat bran in a ratio of $4: 1$, and its moisture content was adjusted to $65 \%$ with distilled water. In order to adjust the $\mathrm{pH}, 1 \% \mathrm{CaCO}_{3}$ was added to the substrate. $1 \mathrm{~kg}$ of the substrate was filled into polypropylene bags with $5 \mu$ pore size filter (Type 14A, Unicorn Bags, TX, USA), autoclaved at $121^{\circ} \mathrm{C}$ for 90 minutes, and then cooled to $25{ }^{\circ} \mathrm{C}$. The sterile substrate was inoculated with five mycelial discs taken from fully colonized plates using a $7 \mathrm{~mm}$ diameter cork borer. After bags were laminated with the heat sealer, they were shaken by hand to distribute the discs into the substrate.

\section{Mushroom cultivation}

Substrate bags were transferred to the climate-controlled room and incubated at $25{ }^{\circ} \mathrm{C}$ with $85 \% \mathrm{RH}$ for the vegetative phase. At this stage, the room was dark, and $\mathrm{CO}_{2}$ was uncontrolled. After the hyphae of Hericium completely covered the bags, six different points on the body of the bags were cut in $3 \mathrm{~cm}$ lengths shaped of the cross for the development of basidiomata. Then generative phase was conducted under the following conditions: at $17^{\circ} \mathrm{C}, 95 \% \mathrm{RH}$, below $800 \mathrm{ppm}$ $\mathrm{CO}_{2}$ concentration, and under artificial lighting for 12 hours a day. Half of the mushrooms, whose fruit body spines were reaching $2 \mathrm{~cm}$, were immediately harvested and named as young fruit body (YFB). The other half of the mushrooms were collected after waiting for five more days and named as overripe fruit body $(\mathrm{OFB})$.

\section{Sample preparation for extractions}

After the mushrooms were cut in $0.5 \mathrm{~cm}$ thickness, they were dried with $\mathrm{MB}$ samples at $40^{\circ} \mathrm{C}$ for $24 \mathrm{~h}$. Dried samples were then powdered using a blade mill (Bosch MKM6000, Germany). After methanol was chosen as the best solvent in preliminary experiments, powdered samples $(1 \mathrm{~g})$ was placed in screw-capped tubes with aqueous methanol at various concentrations. Extraction was performed in a shaking water bath (Wisd, Korea) at the temperature and solvent/solid ratio specified at the experimental design for 60 minutes.

\section{Experimental design and statistical analysis}

The Box-Behnken Design (BBD) of Response Surface Method (RSM) was used to determine the effect of extraction conditions on TPC and 2,2-diphenyl-1picrylhydrazyl (DPPH) antioxidant capacity of samples, as well as to determine the optimized extraction method according to maximized TPC and DPPH. Extraction conditions such as temperature, liquid/solid ratio, and methanol concentration were determined as independent variables and examined at three levels, while TPC and DPPH were selected as responses (Table 1).

$\underline{\text { Table } 1 \text { Levels of independent variables }}$

\begin{tabular}{lccccc}
\hline \multirow{2}{*}{ Independent variables } & \multirow{2}{*}{ Units } & Symbol & \multicolumn{3}{c}{ Coded levels } \\
\cline { 4 - 6 } Temperature & ${ }^{\circ} \mathrm{C}$ & $\mathrm{X}_{1}$ & 30 & 45 & 60 \\
$\begin{array}{l}\text { Liquid/solid ratio } \\
\begin{array}{l}\text { Methanol } \\
\text { concentration }\end{array}\end{array} \mathrm{mL} \mathrm{g}^{-1}$ & $\mathrm{X}_{2}$ & 10 & 20 & 30 \\
\hline
\end{tabular}

Experimental designs consisting of 15 experimental points were created for each of the three samples (MB, YFB, and OFB), as shown in Table 2.

Table 2 Box Behnken design used for Response Surface Methodology with experimental and predicted values for the independent variables

\begin{tabular}{|c|c|c|c|c|c|c|c|c|c|c|c|c|c|c|c|}
\hline \multirow{3}{*}{$\begin{array}{l}\text { Standard } \\
\text { order }\end{array}$} & \multicolumn{3}{|c|}{ Coded variables } & \multicolumn{4}{|c|}{ Mycelial biomass } & \multicolumn{4}{|c|}{ Young fruit body } & \multicolumn{4}{|c|}{ Over-ripe fruit body } \\
\hline & \multirow{2}{*}{$\mathbf{X}_{1}\left({ }^{\circ} \mathrm{C}\right)$} & \multirow{2}{*}{$\begin{array}{c}X_{2} \\
(\%)\end{array}$} & \multirow{2}{*}{$\begin{array}{c}\mathbf{X}_{3} \\
\left(\mathbf{m L} \mathbf{g}^{-1}\right)\end{array}$} & \multicolumn{2}{|c|}{ TPC } & \multicolumn{2}{|c|}{ DPPH } & \multicolumn{2}{|c|}{ TPC } & \multicolumn{2}{|c|}{ DPPH } & \multicolumn{2}{|c|}{ TPC } & \multicolumn{2}{|c|}{ DPPH } \\
\hline & & & & Pre. & Exp. & Pre. & Exp. & Pre. & Exp. & Pre. & Exp. & Pre. & Exp. & Pre. & Exp. \\
\hline $\mathbf{1}$ & -1 & -1 & 0 & 2.18 & 2.18 & 20.67 & 20.97 & 4.58 & 4.69 & 39.00 & 39.11 & 3.13 & 3.17 & 25.45 & 25.22 \\
\hline 2 & 1 & -1 & 0 & 2.43 & 2.37 & 22.64 & 22.55 & 4.99 & 4.97 & 40.04 & 39.97 & 4.06 & 4.10 & 30.03 & 30.23 \\
\hline 3 & -1 & 1 & 0 & 2.22 & 2.28 & 22.05 & 22.14 & 4.91 & 4.93 & 40.27 & 40.34 & 4.01 & 3.97 & 27.97 & 27.77 \\
\hline 4 & 1 & 1 & 0 & 3.14 & 3.14 & 24.79 & 24.49 & 5.27 & 5.16 & 39.70 & 39.59 & 4.17 & 4.12 & 31.36 & 31.59 \\
\hline 5 & -1 & 0 & -1 & 1.52 & 1.49 & 18.47 & 18.25 & 5.02 & 4.94 & 40.34 & 40.25 & 3.74 & 3.79 & 28.39 & 28.99 \\
\hline 6 & 1 & 0 & -1 & 2.31 & 2.35 & 23.47 & 23.64 & 5.29 & 5.34 & 40.24 & 40.33 & 4.20 & 4.25 & 33.08 & 33.24 \\
\hline 7 & -1 & 0 & 1 & 2.59 & 2.55 & 24.30 & 24.13 & 5.18 & 5.13 & 41.85 & 41.76 & 4.10 & 4.05 & 30.33 & 30.17 \\
\hline 8 & 1 & 0 & 1 & 2.97 & 2.99 & 24.00 & 24.22 & 5.68 & 5.76 & 42.42 & 42.51 & 4.74 & 4.69 & 33.60 & 33.00 \\
\hline 9 & 0 & -1 & -1 & 1.76 & 1.79 & 19.20 & 19.12 & 4.29 & 4.27 & 40.14 & 40.12 & 3.83 & 3.74 & 27.94 & 27.58 \\
\hline 10 & 0 & 1 & -1 & 1.98 & 1.94 & 21.23 & 21.36 & 4.53 & 4.59 & 40.53 & 40.55 & 3.99 & 3.98 & 28.71 & 28.32 \\
\hline 11 & 0 & -1 & 1 & 2.47 & 2.51 & 22.64 & 22.51 & 4.51 & 4.45 & 41.91 & 41.89 & 3.94 & 3.95 & 28.02 & 28.41 \\
\hline 12 & 0 & 1 & 1 & 2.99 & 2.97 & 24.15 & 24.23 & 4.87 & 4.89 & 42.45 & 42.47 & 4.78 & 4.87 & 31.10 & 31.46 \\
\hline 13 & 0 & 0 & 0 & 3.67 & 3.64 & 26.82 & 25.70 & 6.09 & 5.98 & 41.58 & 42.22 & 4.84 & 4.91 & 34.15 & 33.10 \\
\hline 14 & 0 & 0 & 0 & 3.67 & 3.66 & 26.82 & 26.85 & 6.09 & 6.10 & 41.58 & 41.13 & 4.84 & 4.83 & 34.15 & 34.89 \\
\hline 15 & 0 & 0 & 0 & 3.67 & 3.72 & 26.82 & 27.90 & 6.09 & 6.20 & 41.58 & 41.39 & 4.84 & 4.79 & 34.15 & 34.47 \\
\hline
\end{tabular}

Legend: Exp.: Experimental values, Pre.; Predicted data

The relationship between factors and variables was expressed using the following equation:

$$
\begin{aligned}
& Y=\beta_{0}+\beta_{1} X_{1}+\beta_{2} X_{2}+\beta_{3} X_{3} \\
& +\beta_{11} X_{1}{ }^{2}+\beta_{22} X_{2}{ }^{2}+\beta_{33} X_{3}{ }^{2} \\
& +\beta_{12} X_{1} X_{2}+\beta_{13} X_{1} X_{3}+\beta_{23} X_{2} X_{3}
\end{aligned}
$$

where; Y: predicted response, $\beta_{0}$ : intercept, $\beta_{1}, \beta_{2}, \beta_{3}$ : linear coefficients, $\beta_{11}, \beta_{22}$, $\beta_{33}$ : interaction coefficients, $\beta_{12}, \beta_{13}, \beta_{23}$ : quadratic coefficients, $X_{1}, X_{2}, X_{3}$ : independent variables.

RSM was performed by using Design Expert 11.0.0 software (Stat-Ease Inc. Minneapolis, MN). Superimposed 3D surface plots were created to compare samples with each other. For this purpose, Design Expert software outputs were processed using Mathematica software (version 7; Wolfram Research, Champaign, IL). The significance of differences between data was determined using the SPSS 22.0 statistics package (SPSS Inc., Chicago, IL)

\section{Total phenolic content}

The TPC of the samples were determined by the method of Singleton et al (1999) with minor modifications, as detailed in our previous study (Doğan et al. 2020).

\section{Antioxidant activity}

DPPH, 2,2'-azino-bis(3-ethylbenzothiazoline-6-sulfonic acid) (ABTS), and ferric reducing ability of plasma (FRAP) were used to determine the antioxidant capacity of the samples. The results of the analysis were expressed as Trolox equivalent ( $\mu \mathrm{M}$ TE/g sample). For DPPH analysis, $0.1 \mathrm{~mL}$ sample was placed in the test tube containing $3.9 \mathrm{~mL}$ of $25 \mathrm{mg} / \mathrm{L}$ concentration of methanolic DPPH solution. After $30 \mathrm{~min}$ of incubation at room temperature in a dark place, the absorbance was read at $515 \mathrm{~nm}$ (Brand-Williams et al., 1995). In ABTS analysis, the ABTS solution, consisting of $30 \mathrm{mg} \mathrm{ABTS}$ and $7.8 \mathrm{~mL}$ of $2.46 \mathrm{mM}$ potassium peroxodisulfate, was incubated for 16 hours. This solution was then diluted with phosphate-buffered saline (PBS) to achieve an absorbance of $0.70 \pm$ 0.05 at $734 \mathrm{~nm}$. After that, $1950 \mu \mathrm{L}$ of diluted ABTS solution and $50 \mu \mathrm{L}$ of the sample was vortexed for $30 \mathrm{~s}$ and absorbance was read after 6 min of incubation (Cam et al., 2009). FRAP analysis was performed according to (Benzie and Strain, 1996). $10 \mu \mathrm{L}$ of sample and FRAP reagent, consisting of $20 \mathrm{mM}$ ferric chloride, $30 \mathrm{mM}$ sodium acetate and $10 \mathrm{mM}$ TPTZ, were mixed in a test tube After 30 min incubation, the absorbance was read at $593 \mathrm{~nm}$

\section{Antidiabetic activity}

Inhibitions of $\alpha$-amylase and $\alpha$-glucosidase analyzes were used to determine the antidiabetic activities of the samples. In $\alpha$-glucosidase analyzes, $50 \mu \mathrm{L}$ sample, $1250 \mu \mathrm{L} 67 \mathrm{mM}$ monopotassium phosphate and $50 \mu \mathrm{L} \alpha$-glucosidase were mixed in a test tube and incubated at $37^{\circ} \mathrm{C}$ for $5 \mathrm{~min}$. $125 \mu \mathrm{L} 10 \mathrm{mM}$ 4-nitrophenyl-Dglucopyranoside solution was added to the tube to start the enzymatic reaction. After $20 \mathrm{~min}, 2 \mathrm{~mL}$ of $0.1 \mathrm{M}$ sodium carbonate was added to the tube to stop the reaction, and the absorbance was read at $400 \mathrm{~nm}$. In $\alpha$-amylase analyzes, $1 \mathrm{~mL}$ sample, $1 \mathrm{~mL}$ potato starch solution, and $1 \mathrm{~mL} 20 \mathrm{mM}$ monosodium phosphate were mixed in a test tube and incubated at $37{ }^{\circ} \mathrm{C}$ for $5 \mathrm{~min} .1 \mathrm{~mL} \alpha$-amylase solution was added to the tube to start the enzymatic reaction. After $30 \mathrm{~min}, 0.5$ $\mathrm{mL}$ of $5.31 \mathrm{M}$ sodium potassium tartrate (prepared with $2 \mathrm{M}$ sodium hydroxide) 
and $0.5 \mathrm{~mL}$ of $96 \mathrm{mM}$ 3,5-dinitrosalicylic acid solution was added to the tube. The mixture was kept in boiling water for 5 minutes to stop the reaction, and then the absorbance was read at $540 \mathrm{~nm}$ (Cam et al., 2020; McDougall et al., 2005) Antidiabetic activity for the two methods described above was calculated using the following equation.

$$
\text { Antidiabetic activity }(\%)=\frac{A B S_{\text {control }}-A B S_{\text {sample }}}{A B S_{\text {control }}} \times 100
$$

where $\mathrm{ABS}_{\text {control }}$ and $\mathrm{ABS}_{\text {sample }}$ express absorbance of control and sample respectively.

Phenolic concentrations of samples that inhibit $50 \%$ of $\alpha$-amylase and $\alpha$ glucosidase were expressed as $\mathrm{IC}_{50}$.

\section{Antimicrobial activity}

The disk diffusion method used to determine antimicrobial activity was performed based on Bauer (1966). The cultures incubated for 16-24 hours were suspended in $0.85 \%$ saline solution to obtain turbidity of $0.5 \mathrm{McFarland}$ standard. Then, suspensions of Bacillus cereus (NRRL-B 37), Staphylococcus aureus (ATCC 25923), Escherichia coli (ATCC 25922), Klebsiella pneumoniae (ATCC 25955) and Candida albicans (ATCC 90028) were inoculated onto Mueller-Hinton agar (MHA) plates. After $10 \mu \mathrm{L}$ of the sample was impregnated to $6 \mathrm{~mm}$ diameter discs, they were placed on plates and incubated $37^{\circ} \mathrm{C}$ for $36 \mathrm{~h}$. Antimicrobial activity was determined by measuring the zone around each disc with a digital caliper.

\section{RESULTS AND DISCUSSION}

\section{Preliminary experiments for solvent selection}

Preliminary experiments based on the highest DPPH and TPC were performed to determine the best solvent among ethanol, methanol, acetone, and distilled water for YFB. 1 gram of dry sample obtained as described in the previous sections was mixed with $20 \mathrm{~mL}$ of solvent having $80 \%$ concentration and incubated at $45^{\circ} \mathrm{C}$ for $60 \mathrm{~min}$. The supernatant was analyzed after separate from the precipitate. The results showed that the highest TPC $(5.06 \pm 0.21 \mathrm{mg}$ GAE $/ \mathrm{g})$ and antioxidan capacity $(43.11 \pm 2.74 \mu \mathrm{mol} \mathrm{TE} / \mathrm{g})$ belonged to methanolic extract as compared to other solvent extracts (Figure 1). In addition to the polarity of solvent and component, the water solubility of components plays a critical role in the separation of bioactive components from the organic material (Barwick, 1997) Snyder's solvent polarity index of ethanol, methanol, acetone, and distilled water is 5.2, 6.6, 5.4, and 9, respectively (Snyder, 1978). Except for hydrosol, a positive correlation was found between TPC, antioxidant capacity, and solvent polarity index (data not shown). The reason for the low extraction performance despite the high polarity index of distilled water may be explained by the fact that some of the bioactive components of Hericium are insoluble in water. On the other hand, methanol is the alcohol with the best ionization potential. This may have caused the anions in H.erinaceus to dissolve more in methanol than othe solvents through facilitated electron transfer (Litwinienko and Ingold, 2003). However, the entire extraction mechanism of the fungal material consisting of many different components with complex interactions may not be explained with a few parameters

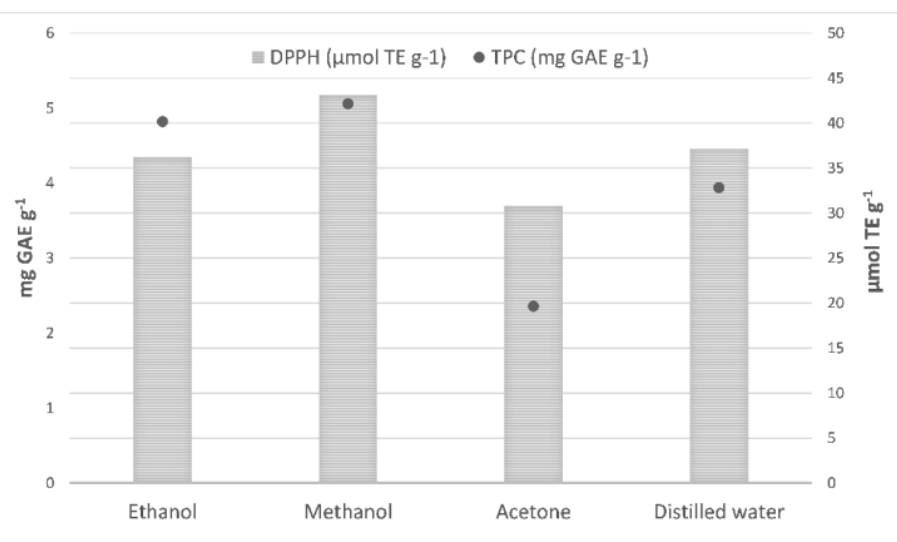

Figure 1 Effects of extraction solvents (ethanol, methanol, acetone and water) on the total phenolic content and antioxidant activity of H.erinaceus

\section{Determination of model accuracy}

The model equations, and statistical parameters such as regression ( $\mathrm{p}$-value), coefficient of determination $\left(R^{2}\right)$, adjusted $R^{2}\left(R_{\text {adj }}^{2}\right)$, predicted $R^{2}\left(R_{\text {pred }}^{2}\right)$ and lack of fit were given in Table 3. The p-value of the analysis of variance (ANOVA) of all responses was found to be less than 0.05 , indicating that the selected model was significant. The experimental and predicted values of the responses in the 15 experimental points were close to each other, which is an indicator of a reliable model (Table 2). The lack of fit determined for the TPC and DPPH of the samples was found insignificant. The $\mathrm{R}^{2}$ values of the responses ranged from 0.956 to 0.997 , which are entirely satisfactory for the quadratic model's ability to predict new values. Furthermore, $\mathrm{R}_{\text {pred }}^{2}$ of responses were in reasonable agreement with their $\mathrm{R}_{\text {adj. }}^{2}$ All statistical evaluations showed that the 2nd order quadratic model obtained from the software could be used to determine the effect of the extraction conditions on the responses, and in the process optimization.

\begin{tabular}{|c|c|c|c|c|c|c|c|}
\hline Sample & Responses & 2 nd order polynomial equations & $\begin{array}{c}\text { Regression } \\
\text { (p-value) }\end{array}$ & $\mathrm{R}^{2}$ & $\mathrm{R}_{\text {adj }}^{2}$ & $\mathrm{R}_{\text {pred }}^{2}$ & $\begin{array}{l}\text { Lack } \\
\text { of fit }\end{array}$ \\
\hline \multirow{2}{*}{ 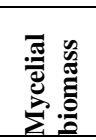 } & ТPC & $\begin{array}{l}3.67+0.294 \mathrm{X}_{1}+0.185 \mathrm{X}_{2}+0.431 \mathrm{X}_{3}+0.168 \mathrm{X}_{1} \mathrm{X}_{2^{-}} \\
0.105 \mathrm{X}_{1} \mathrm{X}_{3}+0.078 \mathrm{X}_{2} \mathrm{X}_{3}-0.569 \mathrm{X}_{1}^{2}-0.612 \mathrm{X}_{2}^{2}-0.759 \mathrm{X}_{3}^{2}\end{array}$ & 0.0001 & 0.997 & 0.992 & 0.960 & 0.248 \\
\hline & DPPH & $\begin{array}{l}26.82+1.18 \mathrm{X}_{1}+0.884 \mathrm{X}_{2}+1.59 \mathrm{X}_{3}+0.192 \mathrm{X}_{1} \mathrm{X}_{2^{-}} \\
1.33 \mathrm{X}_{1} \mathrm{X}_{3}-0.13 \mathrm{X}_{2} \mathrm{X}_{3}-1.76 \mathrm{X}_{1}^{2}-2.52 \mathrm{X}_{2}^{2}-2.49 \mathrm{X}_{3}^{2}\end{array}$ & 0.0024 & 0.971 & 0.920 & 0.880 & 0.947 \\
\hline \multirow{2}{*}{ 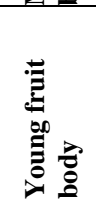 } & TPC & $\begin{array}{l}6.09+0.193 \mathrm{X}_{1}+0.149 \mathrm{X}_{2}+0.136 \mathrm{X}_{3^{-}} \\
0.013 \mathrm{X}_{1} \mathrm{X}_{2}+0.058 \mathrm{X}_{1} \mathrm{X}_{3}+0.030 \mathrm{X}_{2} \mathrm{X}_{3}-0.207 \mathrm{X}_{1}^{2-} \\
0.949 \mathrm{X}_{2}^{2}-0.594 \mathrm{X}_{3}^{2}\end{array}$ & 0.0005 & 0.986 & 0.959 & 0.833 & 0.450 \\
\hline & DPPH & $\begin{array}{l}41.58+0.118 \mathrm{X}_{1}+0.232 \mathrm{X}_{2}+0.922 \mathrm{X}_{3^{-}} \\
0.403 \mathrm{X}_{1} \mathrm{X}_{2}+0.168 \mathrm{X}_{1} \mathrm{X}_{3}+0.038 \mathrm{X}_{2} \mathrm{X}_{3}-0.936 \mathrm{X}_{1}^{2-} \\
0.891 \mathrm{X}_{2}^{2}+0.569 \mathrm{X}_{3}^{2}\end{array}$ & 0.0067 & 0.956 & 0.878 & 0.845 & 0.970 \\
\hline \multirow{2}{*}{ 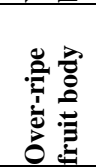 } & ТPC & $\begin{array}{l}4.84+0.273 \mathrm{X}_{1}+0.248 \mathrm{X}_{2}+0.225 \mathrm{X}_{3^{-}} \\
0.195 \mathrm{X}_{1} \mathrm{X}_{2}+0.045 \mathrm{X}_{1} \mathrm{X}_{3}+0.170 \mathrm{X}_{2} \mathrm{X}_{3}-0.472 \mathrm{X}_{1}^{2-} \\
0.532 \mathrm{X}_{2}^{2}-0.177 \mathrm{X}_{3}^{2}\end{array}$ & 0.0003 & 0.988 & 0.967 & 0.841 & 0.255 \\
\hline & DPPH & $\begin{array}{l}34.15+1.99 \mathrm{X}_{1}+0.963 \mathrm{X}_{2}+0.614 \mathrm{X}_{3}-0.298 \mathrm{X}_{1} \mathrm{X}_{2^{-}} \\
0.355 \mathrm{X}_{1} \mathrm{X}_{3}+0.578 \mathrm{X}_{2} \mathrm{X}_{3}-1.52 \mathrm{X}_{1}^{2}-3.93 \mathrm{X}_{2}^{2}-1.28 \mathrm{X}_{3}^{2}\end{array}$ & 0.0025 & 0.971 & 0.919 & 0.748 & 0.681 \\
\hline
\end{tabular}

\section{Effect of the extraction conditions on the TPC}

The effect of extraction process conditions on the TPC value of MB, YFB, and OFB were given in Figure 2.

The level of independent variables applied to all three samples significantly affected the extractable TPC value. Consistent with the mass transfer principle,
TPC increased significantly as the liquid / solid ratio increased from 10 to 20 However, it subsequently decreased. This may be explained by extracting the maximum amount of phenolic when the liquid / solid ratio is at a certain level and decreasing the phenolic concentration of the increasing liquid / solid ratio after this level. 

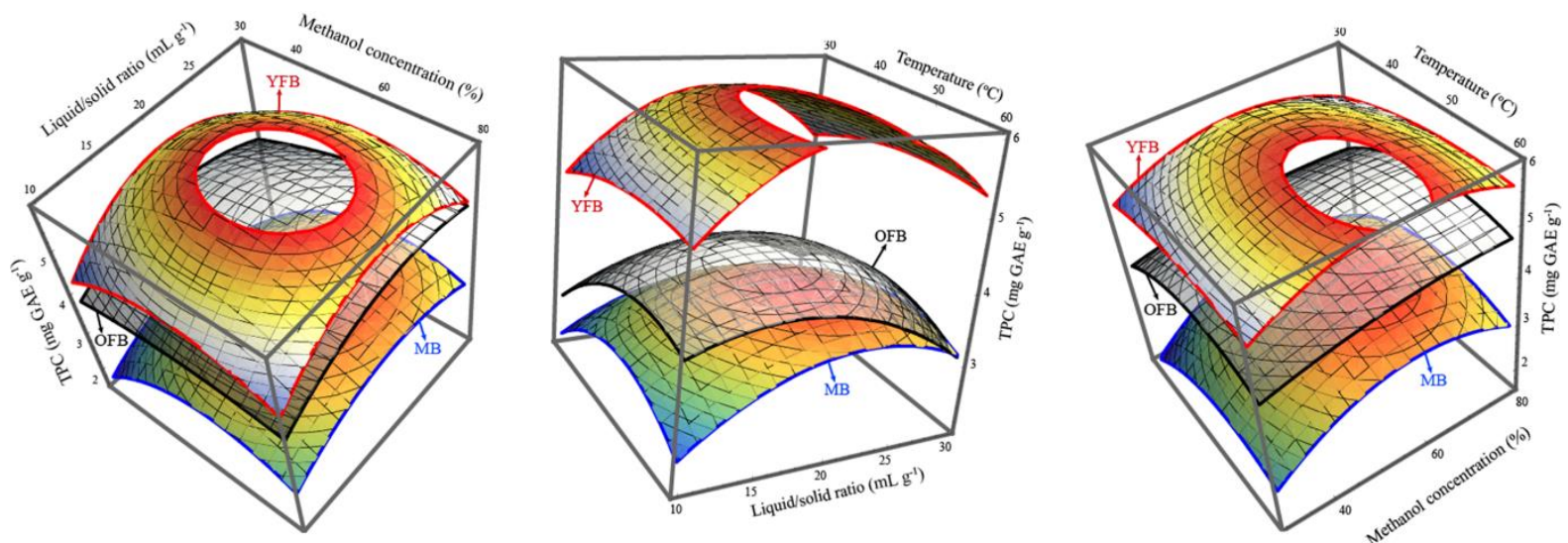

Figure 2 Superimposed 3-D surface plots for effect of the extraction conditions on the total phenolic content of mycelial biomass (MB), young fruit body (YFB) and, over-ripe fruit body (OFB)

Concerning methanol concentration, the TPC of MB and YFB increased with the increase of methanol concentration up to $65 \%$ and $55 \%$, respectively, then slightly decreased. TPC of the OFB increased until the methanol concentration was $70 \%$ and remained constant at its maximum level. The transfer of bioactive components such as phenolics from biomass to solvent largely depends on the difference in polarity between solvent and solute. Therefore, solvents consisting of a combination of alcohol and water can provide more efficient extraction performance than solvents using only one type of alcohol (Markom et al., 2007). Two different situations can be mentioned about the effect of temperature on the recovery of phenolics during the extraction process. The first is that the temperature softens the tissues, increases the solubility of the phenolics, and, accordingly, increases the diffusion ability of the amount of phenolic substance to a certain level. Moreover, high temperature increases the efficiency of phenolic transfer by reducing solvent viscosity and surface tension. The second is that excessive temperature causes the amount of phenolics extracted to decrease as a result of chemical and thermal degradation (Dent et al., 2013). Hence, temperature is one of the most crucial parameters for extraction processes. Herein, considering only the temperature, $48^{\circ} \mathrm{C}$ stood out as the breaking point for TPC of all three samples.

\section{Effect of the extraction conditions on the DPPH}

The effect of variables on the antioxidant capacity of the samples was significant, as shown in Figure 3.
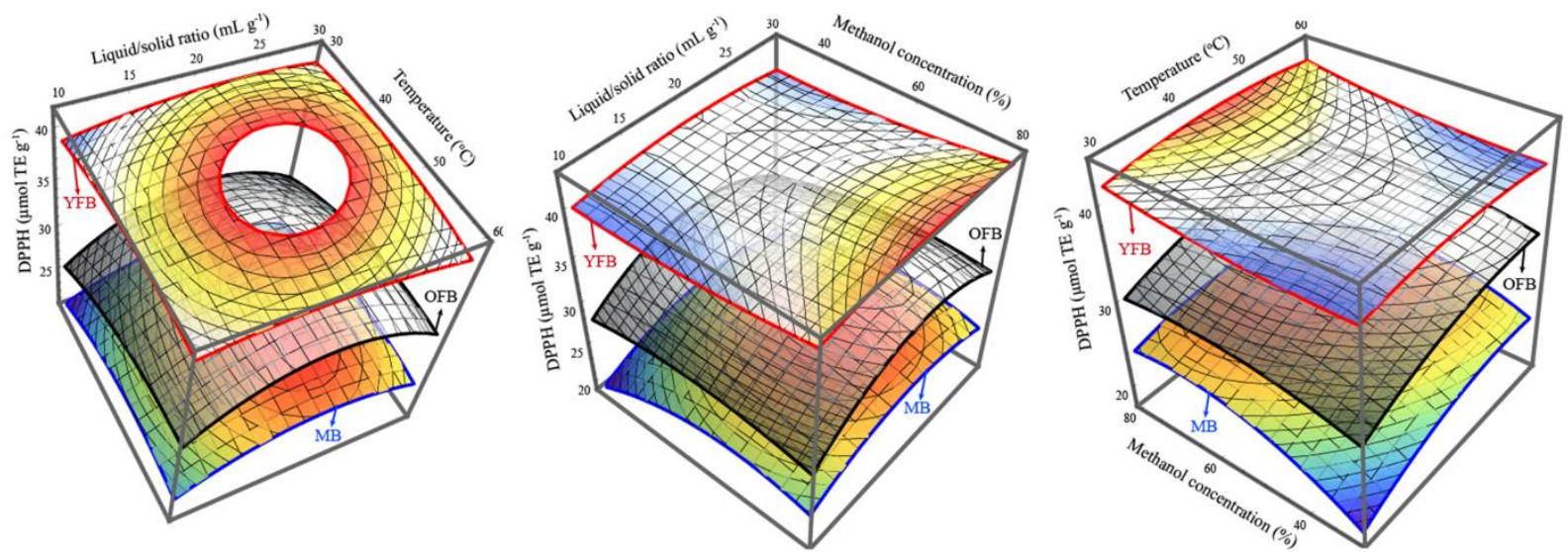

Figure 3 Superimposed 3-D surface plots for effect of the extraction conditions on the antioxidant capacity (DPPH) of mycelial biomass (MB), young fruit body (YFB) and, over-ripe fruit body (OFB)

The effect of the independent variables and the quadratic model was statistically significant for all three samples. When the temperature and liquid/solid ratio were kept constant at a medium level, the curved effect of methanol concentration on antioxidant capacity in MB and OFB samples, as in TPC, was determined. This type of effect is also a sign that there is a positive correlation between TPC and antioxidant capacity since some of the phenolic components have antioxidant effects. In accordance with our study, Liyana-Pathirana and Shahidi (2005) have stated that water-alcohol composite (\%50) solvents showed the highest performance in extracting antioxidant components. However, in the YFB sample, the methanol concentration affected the antioxidant capacity linearly. This result indicated that antioxidant components in YFB that are degraded as the fruit body ages, are probably better soluble in lower polar solvents.

The temperature was another major factor affecting antioxidant capacity, and the antioxidant capacity of all samples continued to increase up to $\sim 48^{\circ} \mathrm{C}$. After this temperature, the antioxidant capacities of MB and YFB partially decreased, while the antioxidant capacity of OFB remained almost constant. Fungi have cell walls formed by crosslinking chitin, glucan, and glycoproteins (Bowman and Free, 2006). The reason for OFB's antioxidant capacity to be positively diverged from other samples after $\sim 48^{\circ} \mathrm{C}$ may be that OFB's thickened cell wall needs higher temperature to release antioxidant compounds, as well as the cell wall provides some protection to compounds that are degraded due to excessive temperature. For all samples, a curved effect of liquid/solid ratio on the antioxidant capacity with a peak of $20 \mathrm{~mL} / \mathrm{g}$, similar to TPC, was determined. This may be explained by the increase in antioxidant components that can contact the solvent as the liquid/solid ratio increases to $20 \mathrm{~mL} / \mathrm{g}$. However, as this rate increased further, the components in the solution may be diluted, and the antioxidant capacity measured may decrease.

\section{Optimization and validation of models}

Numerical optimization was used to determine the most suitable extraction conditions for each fungal sample. Hence, the criteria of dependent variables were set as a maximum for TPC and DPPH. Factor combinations with the highest desirability value were selected as optimum. The desirability approach is a method that assigns "score" to a series of responses and selects factor settings that maximize that score (Natrella, 2010). The optimal levels of independent variables and desirability values for samples are shown in Table 4.

In order to determine the accuracy of the model, the predicted data were compared with the experimental values. Although differences of less than 5\% were detected between experimental and predicted data, they were compatible (Table 4). Hence, it was concluded that the data predicted by the model were dependable. 
Table 4 Optimal extraction conditions with experimental and predicted values at this conditions

\begin{tabular}{|c|c|c|c|c|c|c|c|c|}
\hline \multirow[b]{2}{*}{ Samples } & \multicolumn{4}{|c|}{ Optimal conditions } & \multirow[b]{2}{*}{ Response } & \multirow[b]{2}{*}{$\begin{array}{l}\text { Predicted } \\
\text { value }\end{array}$} & \multirow[b]{2}{*}{$\begin{array}{c}\text { Experimental } \\
\text { value }\end{array}$} & \multirow[b]{2}{*}{$\begin{array}{l}\text { Differences } \\
(\%)\end{array}$} \\
\hline & $\begin{array}{c}\text { Temperature } \\
\left({ }^{\circ} \mathrm{C}\right)\end{array}$ & $\begin{array}{l}\text { Liquid/solid } \\
\text { ratio }\left(\mathrm{mL} \mathrm{g}^{-1}\right)\end{array}$ & $\begin{array}{l}\text { Methanol } \\
\text { conc. }(\%)\end{array}$ & $\begin{array}{l}\text { Desirability } \\
\text { score }\end{array}$ & & & & \\
\hline $\begin{array}{l}\text { Mycelial } \\
\text { biomass }\end{array}$ & 48.7 & 21.8 & 61.2 & 0.96 & $\begin{array}{l}\text { TPC } \\
\text { DPPH }\end{array}$ & $\begin{array}{c}3.79 \\
27.24\end{array}$ & $\begin{array}{c}3.82 \pm 0.32 \\
26.96 \pm 0.85\end{array}$ & $\begin{array}{l}0.79 \\
1.03\end{array}$ \\
\hline $\begin{array}{l}\text { Young fruit } \\
\text { body }\end{array}$ & 49.1 & 20.9 & 72.6 & 0.93 & $\begin{array}{c}\text { TPC } \\
\text { DPPH }\end{array}$ & $\begin{array}{c}5.95 \\
42.51\end{array}$ & $\begin{array}{c}5.87 \pm 0.41 \\
43.11 \pm 2.74\end{array}$ & $\begin{array}{l}1.35 \\
1.41\end{array}$ \\
\hline $\begin{array}{l}\text { Over-ripe fruit } \\
\text { body }\end{array}$ & 53.4 & 21.2 & 60.8 & 0.98 & $\begin{array}{c}\text { TPC } \\
\text { DPPH }\end{array}$ & $\begin{array}{c}4.91 \\
34.87\end{array}$ & $\begin{array}{c}4.89 \pm 0.63 \\
33.56 \pm 1.31\end{array}$ & $\begin{array}{l}0.41 \\
3.76\end{array}$ \\
\hline
\end{tabular}

\section{Antioxidant and antidiabetic capacity}

The antioxidant and antidiabetic effects of optimized extracts are given in Table 5. The hierarchy of antioxidant and antidiabetic effects of samples in all analysis methods was following: $\mathrm{YFB}>\mathrm{OFB}>\mathrm{MB}$. Oxygen radicals are cancer-related molecules that can cause DNA, RNA, and protein damage within the cell. Antioxidants can be protective against cancer because they inhibit these radicals (Lambert and Elias, 2010). In this study, DPPH, FRAP, and ABTS were used to evaluate antioxidant capacity because the mechanisms of antioxidants to inhibit radicals are different. DPPH, FRAP and ABTS values of young fruit were 59.9\%, $30.9 \%$, and $39.2 \%$ higher than mycelia, respectively. But when the fruit body aged, it lost its antioxidant effect by $22.2 \%, 17.2 \%$, and $10.6 \%$, respectively. Probably the aging process increases oxidative reactions, which speeds up the breakdown of antioxidant components. The results were higher than in the previous study (Atila et al., 2018), where the FRAP value ranged from 1.76 to $4.92 \mu \mathrm{mol} \mathrm{TE} / \mathrm{g}$. Moreover, unlike our result, Wong et al. (2009) reported that H.erinaceus mycelium extract had a higher antioxidant effect than the fruit body. These differences may have resulted from the uniqueness of the extraction process conditions obtained as a result of optimization in our study.
One of the primary treatment approaches for type 2 diabetes is based on the inhibition of enzymes such as $\alpha$-glucosidase and $\alpha$-amylase that break down carbohydrates. In this study, the effectiveness of optimized extracts in inhibiting these enzymes was tested. D-threitol, D-arabinitol, palmitic acid, and $\alpha$-D-glucan are important components that show antidiabetic effects in H.erinaceus (Wang et al., 2005). The antidiabetic effect of YFB was more than MB, and this effect was found to be low in OFB, probably because the components as mentioned earlier were degraded by aging of the fruit. In a study, the antidiabetic effect of different mushroom varieties was investigated (Stojkovic et al., 2019). Accordingly, YFB showed lower $\alpha$-amylase inhibition than A.blazei and P.linteus, whereas it showed higher alpha $\alpha$-glucosidase inhibition than the same mushrooms. In another study, $\alpha$-amylase and $\alpha$-glucosidase $\mathrm{IC}_{50}$ value of P.florida was determined as $35.96 \pm 0.35 \mu \mathrm{g} / \mathrm{mL}$ and $202.02 \pm 3.84 \mu \mathrm{g} / \mathrm{mL}$, respectively (Prabu and Kumuthakalavalli, 2017) People with diabetes may take acarbose, an antidiabetic drug, at an initial dose of $3 \times 25 \mathrm{mg}$ daily (Lebovitz, 1995). With the calculation made according to the inhibition of $\alpha$-glucosidase by acarbose, it was concluded that YFB powder might be taken at a dose of 3x66.36 g/day (Table 5).

Table 5 Antioxidant and antidiabetic activity of samples

\begin{tabular}{|c|c|c|c|c|c|c|c|}
\hline \multirow[b]{2}{*}{ Sample } & \multirow[b]{2}{*}{ 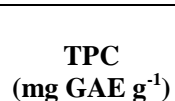 } & \multicolumn{3}{|c|}{ Antioxidant capacity } & \multicolumn{3}{|c|}{ Antidiabetic activity } \\
\hline & & $\begin{array}{c}\text { DPPH } \\
\left(\mu \mathrm{mol} \mathrm{TE} \mathrm{g}^{-1}\right)\end{array}$ & $\begin{array}{c}\text { FRAP } \\
\left(\mu \mathrm{mol} \mathrm{TE} \mathrm{g}^{-1}\right)\end{array}$ & $\begin{array}{c}\text { ABTS } \\
\left(\mu \mathrm{mol} \mathrm{TE} \mathrm{g}^{-1}\right)\end{array}$ & $\begin{array}{c}\alpha \text {-glucosidase } \mathrm{IC}_{50} \\
\left(\mu \mathrm{g} \mathrm{mL} \mathrm{L}^{-1}\right)\end{array}$ & $\begin{array}{c}\alpha \text {-amylase } \mathrm{IC}_{50} \\
\left(\mu \mathrm{g} \mathrm{mL}^{-1}\right)\end{array}$ & DDR \\
\hline Mycelial biomass & $3.82 \pm 0.32^{\mathrm{c}}$ & $26.96 \pm 0.85^{\mathrm{c}}$ & $39.27 \pm 1.12^{\mathrm{c}}$ & $45.14 \pm 0.64^{\mathrm{c}}$ & $186.77 \pm 1.61^{\mathrm{a}}$ & $226.61 \pm 0.44^{\mathrm{a}}$ & $3 \times 132.5 \mathrm{~g}$ \\
\hline Young fruit body & $5.87 \pm 0.41^{\mathrm{a}}$ & $43.11 \pm 2.74^{\mathrm{a}}$ & $51.39 \pm 2.34^{\mathrm{a}}$ & $62.84 \pm 1.59^{\mathrm{a}}$ & $93.54 \pm 2.3^{\mathrm{c}}$ & $132.25 \pm 1.38^{\mathrm{c}}$ & $3 \times 66.36 \mathrm{~g}$ \\
\hline Over-ripe fruit body & $4.89 \pm 0.63^{\mathrm{b}}$ & $33.56 \pm 1.31^{\mathrm{b}}$ & $42.53 \pm 0.93^{b}$ & $56.17 \pm 2.97^{\mathrm{b}}$ & $137.21 \pm 2.15^{\mathrm{b}}$ & $191.72 \pm 0.56^{\mathrm{b}}$ & $3 \times 97.34 \mathrm{~g}$ \\
\hline Acarbose & - & - & - & - & $35.24 \pm 1.73^{\mathrm{d}}$ & $72.96 \pm 3.18^{\mathrm{d}}$ & $3 \times 25 \mathrm{mg}$ \\
\hline
\end{tabular}

\section{Antimicrobial capacity}

Antimicrobial activities of the optimized extracts were evaluated according to the diameter of the inhibition zone, as in Table 6. While MB showed moderate level inhibition against Gram-positive bacteria B. cereus and S.aureus, YFB showed moderate level inhibition against B.cereus and high-level inhibition against S.aureus. All samples showed a low level of inhibition against Gram-negative bacteria E.coli and K.pneumoniae. Against to C.albicans, a pathogenic fungus, only YFB had an antimicrobial effect, but it was low level. Antimicrobial capacity tests clearly demonstrated that H.erinaceus had more inhibitory effects against Gram-positive bacteria than Gram-negative bacteria. This can be explained by the fact that Gram-negative bacteria have an outer membrane that makes them resistant to many antibiotics (Nikaido and Vaara, 1985). The results were in agreement with Wong et al. (2009) and D.-M. Kim et al. (2000).

Table 6 Antimicrobial activity of samples

\begin{tabular}{lccccc}
\hline Sample & B. cereus & S. aureus & E. coli & K. pneumoniae & C. albicans \\
\hline $\begin{array}{l}\text { Mycelial biomass } \\
\text { Young fruit body }\end{array}$ & ++ & ++ & + & + & ND \\
$\begin{array}{l}\text { Over-ripe fruit } \\
\text { body }\end{array}$ & ++ & +++ & + & + & + \\
\hline
\end{tabular}

Legend: Diameter of inhibition zone: + low level of activity (8 to $15 \mathrm{~mm}),++$ moderate level of activity (15 to $21 \mathrm{~mm}),+++$ high

level of activity (>21 mm), ND not determined

\section{CONCLUSION}

RSM was successfully applied in the optimization of extraction conditions that maximize antioxidant capacity and phenolic content in this study. Optimization results showed that the best conditions for the extraction process were at an average of $50.4{ }^{\circ} \mathrm{C}, 21.3 \mathrm{~mL} / \mathrm{g}$ liquid to solid ratio, and $64.87 \%$ methanol concentration. Results indicated that the optimized extracts also had high levels of antioxidant, antimicrobial, and antidiabetic effects. Also, the harvest time of H.erinaceus played an essential role in these effects. Although mycelial biomass bioactivity was less than the fruit body, it cannot be ignored due to its short production time and relatively easy production process.

Optimization of the green-novel extraction processes should be investigated in more detail based on the biofunctional properties of H.erinaceus that are very important for human health.

Acknowledgments: This work was financially supported by Yozgat Bozok University Scientific Research Projects Unit (Project No: 6602b-BMYO/17-125).

\section{REFERENCES}

Atila, F., Tuzel, Y., Fernández, J. A., Cano, A. F., \& Sen, F. (2018). The effect of some agro-industrial wastes on yield, nutritional characteristics and antioxidant activities of Hericium erinaceus isolates. Scientia Horticulturae, 238, 246-254. https://doi.org/10.1016/j.scienta.2018.04.049

Barwick, V. J. (1997). Strategies for solvent selection-a literature review. TrAC Trends in Analytical Chemistry, 16(6), 293-309. https://doi.org/10.1016/S0165 9936(97)00039-3

Bauer, A. (1966). Antibiotic susceptibility testing by a standardized single disc method. Am J clin pathol, 45, 149-158.

Benzie, I. F., \& Strain, J. J. (1996). The ferric reducing ability of plasma (FRAP) as a measure of "antioxidant power": the FRAP assay. Analytical biochemistry 239(1), 70-76. https://doi.org/10.1006/abio.1996.0292

Bowman, S. M., \& Free, S. J. (2006). The structure and synthesis of the fungal cell wall. Bioessays, 28(8), 799-808. https://doi.org/10.1002/bies.20441 
Box, G. E., \& Wilson, K. B. (1992). On the experimental attainment of optimum conditions Breakthroughs in statistics (pp. 270-310): Springer. https://doi.org/10.1111/j.25176161.1951.tb00067.x

Brand-Williams, W., Cuvelier, M.-E., \& Berset, C. (1995). Use of a free radica method to evaluate antioxidant activity. LWT-Food Science and Technology, 28(1), 25-30. https://doi.org/10.1016/S0023-6438(95)80008-5

Cam, M., Basyigit, B., Alasalvar, H., Yilmaztekin, M., Ahhmed, A., Sagdic, O., .. \& Telci, I. (2020). Bioactive properties of powdered peppermint and spearmint extracts: Inhibition of key enzymes linked to hypertension and type 2 diabetes. Food Bioscience, 35, 100577. https://doi.org/10.1016/j.fbio.2020.100577

Çam, M., Hış1l, Y., \& Durmaz, G. (2009). Classification of eight pomegranate juices based on antioxidant capacity measured by four methods. Food chemistry, 112(3), 721-726. https://doi.org/10.1016/j.foodchem.2008.06.009

Chirinos, R., Rogez, H., Campos, D., Pedreschi, R., \& Larondelle, Y. (2007) Optimization of extraction conditions of antioxidant phenolic compounds from mashua (Tropaeolum tuberosum Ruíz \& Pavón) tubers. Separation and Purification Technology,

$217-225$

https://doi.org/10.1016/j.seppur.2006.12.005

Dent, M., Dragović-Uzelac, V., Penić, M., Bosiljkov, T., \& Levaj, B. (2013). The effect of extraction solvents, temperature and time on the composition and mass fraction of polyphenols in Dalmatian wild sage (Salvia officinalis L.) extracts. Food Technology and Biotechnology, 51(1), 84-91.

Doğan, N., Doğan, C., Çam, M., \& Hayoğlu, İ. (2020). Optimization and comparison of three cooking methods for wheat flour-oyster mushroom (P. ostreatus) powder composite chips. Journal of Food Processing and Preservation, e14873. https://doi.org/10.1111/jfpp.14873

Fang, Q.-H., \& Zhong, J.-J. (2002). Submerged fermentation of higher fungus Ganoderma lucidum for production of valuable bioactive metabolites - ganoderic acid and polysaccharide. Biochemical Engineering Journal, 10(1), 61-65. https://doi.org/10.1016/S1369-703X(01)00158-9

Ferreira, I. C., Barros, L., \& Abreu, R. (2009). Antioxidants in wild mushrooms. Current Medicinal Chemistry, 16(12), 1543-1560. https://doi.org/10.2174/092986709787909587

Gogoi, P., Chutia, P., Singh, P., \& Mahanta, C. L. (2019). Effect of optimized ultrasound-assisted aqueous and ethanolic extraction of Pleurotus citrinopileatus mushroom on total phenol, flavonoids and antioxidant properties. Journal of Food Process Engineering, 42(6), e13172. https://doi.org/10.1111/jfpe.13172

Kim, D.-M., Pyun, C.-W., Ko, H.-G., \& Park, W.-M. (2000). Isolation of antimicrobial substances from Hericium erinaceum. Mycobiology, 28(1), 33-38. https://doi.org/10.1080/12298093.2000.12015719

Kim, S. P., Kang, M. Y., Kim, J. H., Nam, S. H., \& Friedman, M. (2011). Composition and mechanism of antitumor effects of Hericium erinaceus mushroom extracts in tumor-bearing mice. Journal of agricultural and food chemistry, 59(18), 9861-9869. https://doi.org/10.1021/jf201944n

Ko, H. G., Park, H. G., Park, S. H., Choi, C. W., Kim, S. H., \& Park, W. M (2005). Comparative study of mycelial growth and basidiomata formation in seven different species of the edible mushroom genus Hericium. Bioresource technology, 96(13), 1439-1444. https://doi.org/10.1016/j.biortech.2004.12.009

Lambert, J. D., \& Elias, R. J. (2010). The antioxidant and pro-oxidant activities of green tea polyphenols: a role in cancer prevention. Archives of biochemistry and biophysics, 501(1), 65-72. https://doi.org/10.1016/j.abb.2010.06.013

Lebovitz, H. E. (1995). A new oral therapy for diabetes management: alphaglucosidase inhibition with acarbose. Clinical diabetes, 13(6), 99-104.

Lee, J. S., \& Hong, E. K. (2010). Hericium erinaceus enhances doxorubicininduced apoptosis in human hepatocellular carcinoma cells. Cancer letters, 297(2), 144-154. https://doi.org/10.1016/j.canlet.2010.05.006

Lee, J. S., Cho, J. Y., \& Hong, E. K. (2009). Study on macrophage activation and structural characteristics of purified polysaccharides from the liquid culture broth of Hericium erinaceus. Carbohydrate Polymers, 78(1), 162-168 https://doi.org/10.1016/j.carbpol.2009.04.036

Li, Q.-Z., Wu, D., Chen, X., Zhou, S., Liu, Y., Yang, Y., \& Cui, F. (2015). Chemical compositions and macrophage activation of polysaccharides from Leon's mane culinary-medicinal mushroom Hericium erinaceus (higher basidiomycetes) in different maturation stages. International journal of medicinal mushrooms, 17(5). https://doi.org/10.1615/IntJMedMushrooms.v17.i5.40

Litwinienko, G., \& Ingold, K. (2003). Abnormal solvent effects on hydrogen atom abstractions. The reactions of phenols with 2, 2-diphenyl-1-picrylhydrazyl (dpph•) in alcohols. The Journal of organic chemistry, 68(9), 3433-3438. https://doi.org/10.1021/jo026917t

Liyana-Pathirana, C., \& Shahidi, F. (2005). Optimization of extraction of phenolic compounds from wheat using response surface methodology. Food chemistry, 93(1), 47-56. https://doi.org/10.1016/j.foodchem.2004.08.050

Markom, M., Hasan, M., Daud, W. R. W., Singh, H., \& Jahim, J. M. (2007). Extraction of hydrolysable tannins from Phyllanthus niruri Linn.: Effects of solvents and extraction methods. Separation and Purification Technology, 52(3), 487-496. https://doi.org/10.1016/j.seppur.2006.06.003

McDougall, G. J., Shpiro, F., Dobson, P., Smith, P., Blake, A., \& Stewart, D (2005). Different polyphenolic components of soft fruits inhibit $\alpha$-amylase and $\alpha$ glucosidase. Journal of agricultural and food chemistry, 53(7), 2760-2766. https://doi.org/10.1021/jf0489926
Nakatsugawa, M., Takahashi, H., Takezawa, C., Nakajima, K., Harada, K., SuGAWARA, Y., . . \& \& Abe, S. (2003). Hericium erinaceum (yamabushitake) extract-induced acute respiratory distress syndrome monitored by serum surfactant proteins. Internal medicine, 42(12), 1219-1222. https://doi.org/10.2169/internalmedicine.42.1219

Natrella, M. (2010). NIST/SEMATECH e-handbook of statistical methods. Nist/Sematech, 49.

Nikaido, H., \& Vaara, M. (1985). Molecular basis of bacterial outer membrane permeability. Microbiological reviews, $49(1), \quad 1$ https://doi.org/10.1128/MMBR.67.4.593-656.2003

Prabu, M., \& Kumuthakalavalli, R. (2017). Antidiabetic potential of the oyster mushroom Pleurotus florida (Mont.) singer. Int J Curr Pharm Res, 9(4), 51-54. http://dx.doi.org/10.22159/ijcpr.2017v9i4.20765

Singleton, V. L., Orthofer, R., \& Lamuela-Raventós, R. M. (1999). Analysis of total phenols and other oxidation substrates and antioxidants by means of folinciocalteu reagent Methods in enzymology (Vol. 299, pp. 152-178): Elsevier. https://doi.org/10.1016/S0076-6879(99)99017-1

Snyder, L. (1978). Classification off the solvent properties of common liquids Journal of Chromatographic Science, 16(6), 223-234. https://doi.org/10.1093/chromsci/16.6.223

Stamets, P. (2011). Growing gourmet and medicinal mushrooms: Ten Speed Press.

Stojkovic, D., Smiljkovic, M., Ciric, A., Glamoclija, J., Van Griensven, L., Ferreira, I. C.,...\& Sokovic, M. (2019). An insight into antidiabetic properties of six medicinal and edible mushrooms: Inhibition of $\alpha$-amylase and $\alpha$-glucosidase linked to type-2 diabetes. South African Journal of Botany, 120, 100-103. https://doi.org/10.1016/i.sajb.2018.01.007

Wang, J. C., Hu, S. H., Wang, J. T., Chen, K. S., \& Chia, Y. C. (2005) Hypoglycemic effect of extract of Hericium erinaceus. Journal of the Science of Food and Agriculture, 85(4), 641-646. https://doi.org/10.1002/jsfa.1928

Wong, K. H., Sabaratnam, V., Abdullah, N., Kuppusamy, U. R., \& Naidu, M (2009). Effects of cultivation techniques and processing on antimicrobial and antioxidant activities of Hericium erinaceus (Bull.: Fr.) Pers. extracts. Food Technology and Biotechnology, 47(1), 47-55.

XuJie, H., \& Wei, C. (2008). Optimization of extraction process of crude polysaccharides from wild edible $\mathrm{BaChu}$ mushroom by response surface methodology. Carbohydrate Polymers, 72(1), 67-74. https://doi.org/10.1016/j.carbpol.2007.07.034 